\title{
Nerve Growth Factor (NGF) Prevents the Shift in Ocular Dominance Distribution of Visual Cortical Neurons in Monocularly Deprived Rats
}

\author{
Lamberto Maffei,, ${ }^{1,2}$ Nicoletta Berardi, ${ }^{1}$ Luciano Domenici, ${ }^{1}$ Vincenzo Parisi, ${ }^{1}$ and Tommaso Pizzorusso ${ }^{2}$ \\ IIstituto di Neurofisiologia del CNR and '2Scuola Normale Superiore, 56100 Pisa, Italy
}

The hypothesis that NGF could play a role in the plasticity of the developing mammalian visual cortex was tested in monocularly deprived (MD) rats. In particular, we have asked whether an exogenous supply of NGF could prevent the changes in ocular dominance distribution induced by monocular deprivation.

Hooded rats were monocularly deprived for 1 month, starting at postnatal day 14 (P14), immediately before eye opening, by means of eyelid suture. In eight rats, only monocular deprivation was performed; in eight rats, monocular deprivation was combined with intraventricular injections of $\beta$-NGF, and in three rats, with intraventricular injections of cytochrome C. Injections $(2 \mu l)$ were given every other day for a period of 1 month.

Single neuron activity was recorded in the primary visual cortex of MD rats, MD rats treated with NGF, and MD rats treated with cytochrome $\mathrm{C}$ at the end of the deprivation period, and in normal rats of the same age.

We found that monocular deprivation caused a striking change in the ocular dominance distribution of untreated MD rats, reducing binocular cells by a factor of two and increasing by a factor of eight the number of cells dominated by the nondeprived eye. In MD NGF-treated rats, the ocular dominance distribution was indistinguishable from the normal. Cytochrome $\mathrm{C}$ treatment was completely ineffective in preventing the ocular dominance shift induced by monocular deprivation.

To test whether NGF affected cortical physiology or interfered with transmission of visual information, we evaluated in NGF-treated rats the spontaneous discharge and the orientation selectivity. We found these functional properties to be in the normal range.

We conclude that NGF is effective in preventing the effects of monocular deprivation in the rat visual cortex and suggest that NGF is a crucial factor in the competitive processes leading to the stabilization of functional geniculocortical connections during the critical period.

\footnotetext{
Received Feb. 19, 1992; revised May 22, 1992; accepted May 29, 1992.

We gratefully acknowledge the generous gift of NGF from FIDIA Research Laboratories, Abano T., Italy. We thank Prof. A. Fiorentini and Dr. G. Carmignoto for helpful discussions, Prof. D. C. Burr for reading the manuscript, and A. Tacchi, P. Taccini, G. C. Cappagli, M. Antoni, and A. Alpigiani for technical help. Miss M. Fagiolini took part in some of the experiments. Mr. David Perazzoni drew Fig. 1. Drs. D. C. Burr and M. C. Morrone provided the software for cell recording. Dr. G. Tinivella kindly helped with the statistical analysis. N.B. is associate professor at the Department of General and Environmental Physiology, University of Naples.

Correspondence should be addressed to Lamberto Maffei, Istituto di Neurofisiologia del CNR, Via S. Zeno, 51, 56127 Pisa, Italy.

Copyright (C) 1992 Society for Neuroscience $0270-6474 / 92 / 124651-12 \$ 05.00 / 0$
}

Depriving one eye of patterned vision during early postnatal development (critical period) modifies the balance of input from the two eyes onto individual neurons in the mammalian visual corlex. Most visual cortical neurons loose their functional input from the deprived eye, and the distribution of cell ocular dominance changes in favor of the nondeprived eye (Wiesel and Hubel, 1963; Baker et al., 1974; Dräger, 1978; Boothe et al., 1985; Berardi et al., 1991). The deprived eye becomes amblyopic: its visual acuity is strongly diminished and its contrast sensitivity depressed (Giffin and Mitchell, 1978; Harwerth et al., 1989; Domenici et al., 1991a,c).

Anatomically, monocular deprivation performed during the critical period results in the reduction of the territories occupied in the primary visual cortex by the terminals from the deprived laminae of the LGN and the complementary expansion of the territories occupied by the inputs from the nondeprived laminae (Shatz and Stryker, 1978; LeVay et al., 1980). In addition, there is a substantial degree of shrinkage for $L G N$ projection cells in the deprived laminae, but only in the portion corresponding to the representation of the binocular visual field (Guillery and Stelzner, 1970; Sherman et al., 1974).

The effects of monocular deprivation are thought to be the outcome of competition between the inputs from the ipsilateral and contralateral laminae of the LGN in synapse formation onto binocular cortical neurons, competition that normally leads to their segregation into separate territories.

As a consequence of monocular deprivation, the eye with normal vision dominates the cortical input. Binocular neurons are strongly diminished, and most cortical cells stop responding to the deprived eye.

The presumed underlying mechanism is that cortical synapses receiving stronger electrical messages become functionally and structurally strengthened. As postulated by Hebb (1949), the correlated activity between the pre- and postsynaptic neurons represents an essential prerequisite for synaptic strengthening also in the visual cortex (Kasamatsu and Pettigrcw, 1976; Shaw and Cynader, 1984; Stryker and Strickland, 1984; Bear and Singer, 1986; Reiter and Stryker, 1987; Ramoa et al., 1989; Bear et al., 1990; Shatz, 1990).

Two crucial questions still remain to be answered: what the axons from the LGN are competing for, and what is the process by which synapses receiving stronger or better organized electrical messages become functionally and structurally strengthened?

We have formulated the hypothesis that the strengthening of synaptic contacts could be based on the acquisition of a trophic factor, present in limited amount in the target structure. The production and release of this factor, and possibly its uptake, are supposed to be dependent on electrical activity (thus cor- 

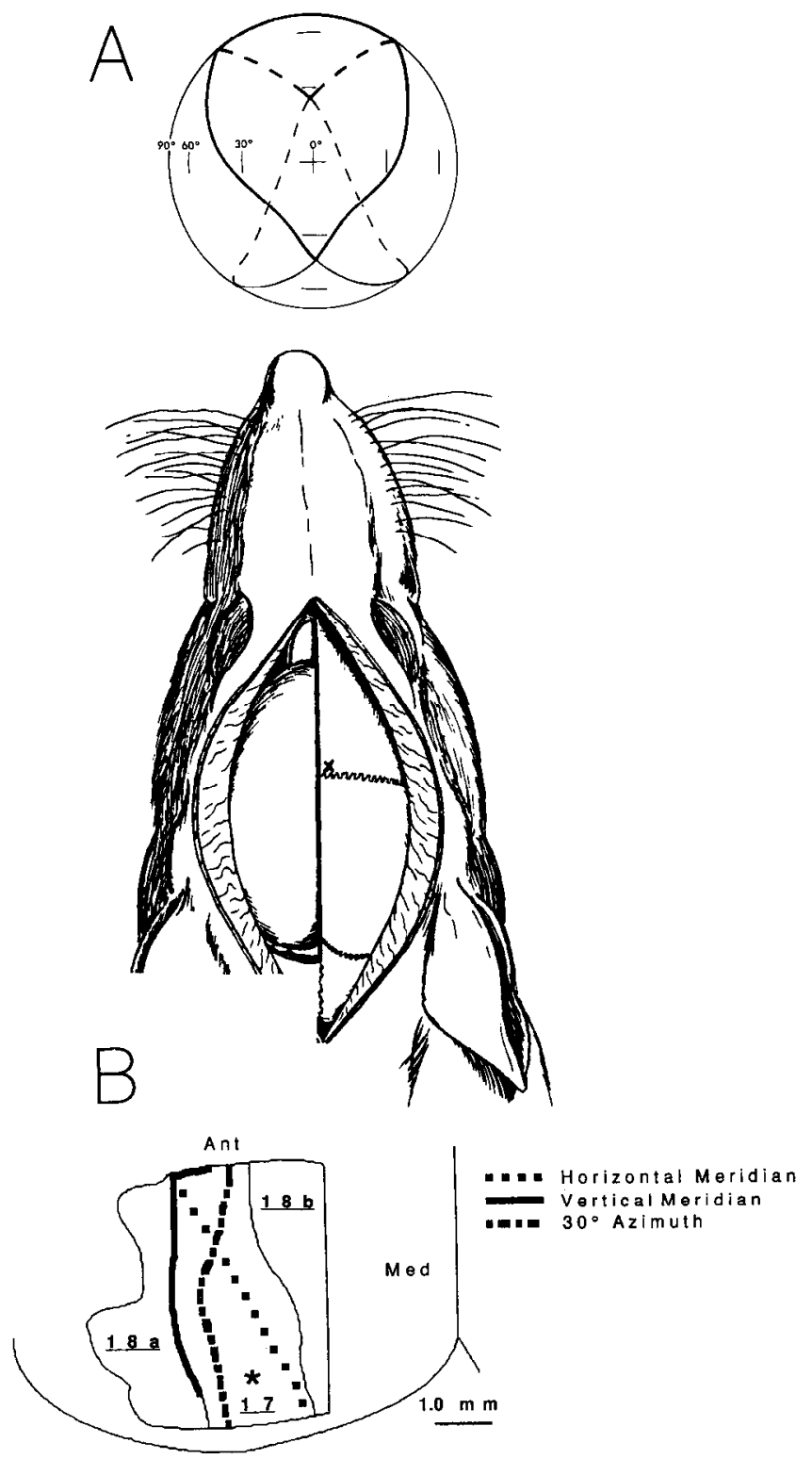

Figure 1. A, Rat visual field; the heavier lines indicate the binocular part. Numbers refer to eccentricities along the horizontal meridian. The broken lines define the limit of each monocular visual field behind the rat (adapted from Hughes, 1979). $B$, Representation of the left visual cortex with the landmarks of the contralateral visual field (adapted from Sefton and Dreher, 1985). Our sample of cells was collected between the projection of the vertical meridian and $30^{\circ}$ azimuth. The cross on bregma in the drawing indicates the site for intraventricular injections.

responding to the activity-dependent reward postulated by Hebb). The activity in the LGN fibers driven by the deprived eye would be insutficient or, more likely, inappropriate for the necessary production and/or uptake of the neurotrophic factor. Loss in competition would therefore be equivalent to lack of neurotrophic factor for the axons driven by the deprived eye; the synapses would loose their strength and eventually hecome ineffective in driving the postsynaptic target. Correspondingly, cell bodies in the LGN deprived laminae would shrink.

We have tested this hypothesis by exogenously supplying a neurotrophic factor to monocularly deprived (MD) rats during the critical period and investigating whether the availability of trophic substance would eliminate competition between the two visual inputs, thus preventing the effects of monocular deprivation. The neurotrophic factor we have tested has been NGF (see Levi-Montalcini, 1987). The choice of NGF has been prompted by the fact that NGF is widely expressed in the visual pathways and in particular in the visual cortex of mammals (rat and monkey), with a characteristic pattern of variation through the postnatal development (Large et al., 1986; Hayashi et al., 1990; Crcmisi ct al., 1991), and that the action of NGF is well characterized both in the PNS and in the CNS (Hendry, 1989; Carmignoto et al., 1989; Araujo et al., 1990; Thoenen, 1991).

The results we have obtained are clear in indicating that when NGF is exogenously provided, the effects of monocular deprivation on the ocular dominance distribution do not take place.

In a previous work (Berardi et al., 1990; Domenici et al., $1991 \mathrm{a}, \mathrm{c})$, we have reported that in NGF-treated rats, visual acuity and contrast sensitivity, evaluated electrophysiologically with visual evoked potentials, are also unaffected by monocular deprivation.

\section{Materials and Methods}

Animal treatment. A total of 37 Long-Evans hooded rats were used. Fourteen rats were normal. Nineteen rats were monocularly deprived for 1 month by means of eyelids suture starting immediately before eye opening [postnatal day 14 (P14)]. In eight rats, only monocular deprivation was performed. In eight rats, deprivation was combined with the intraventricular injection of a solution containing $\beta$-NGF (FIDIA Research Laboratories, Abano Terme, Italy; $1-1.6 \mu \mathrm{g} / \mu \mathrm{l}$ in buffered saline). In three rats, cytochrome $C(1 \mu \mathrm{g} / \mu \mathrm{l}$ in buffered saline) was injected with the same protocol as for NGF, to control for possible aspecific effects of NGF treatment (e.g., animal handling, anesthesia, i.v. injections of NGF). Cytochrome $C$ is a molecule generally used to control for NGF effects (Kromer, 1987; Hendry, 1989). Four rats were left undeprived and were treated with NGF following the same protocol.

Injections (volume injected, $2 \mu \mathrm{l}$ ) were repeated every $2 \mathrm{~d}$ for a period of 1 month by means of a microsyringe connected to a cannula ( 27 gauge) acutely inserted through a hole $1 \mathrm{~mm}$ lateral and in correspondence with bregma to reach the right lateral ventricle (Vantini et al., 1989). To check that the injections effectively reached the ventricle, a dye (Pontamine sky blue) was injected with the same procedure and was invariably found in the ventricles. According to previous controls, the diffusion of NGF within the cerebral tissue is at least $3-4 \mathrm{~mm}$ (Domenici et al., 1991a). Injections were well tolerated and no gross behavioral effect was found following intraventricular NGF; rats were normally active and both feeding behavior and body weight were in the normal range, such that NGF-treated animals were indistinguishable from untreated and cytochrome C-treated animals.

Eyelids suture and intraventricular injections were performed under ether anesthesia.

Single-cell recording. Six of the normal rats were recorded during the critical period (P19, $N=3 ; \mathrm{P} 27, N=3$ ); the remaining eight normal rats and all monocularly deprived rats were recorded at the end of the presumed critical period ( $>$ P45). Two of the monocularly deprived NGF-treated rats were recorded during the treatment (P42), and four undeprived NGF-treated rats were recorded during the treatment and within the presumed critical period (P19, $N=2 ; \mathrm{P} 27, N=2)$ in order to evaluate possible transient effects of NGF on neuronal excitability and on the quality of the cell visual response.

To record single cortical unit activity, the animals were anesthetized in urethane $(6 \mathrm{cc} / \mathrm{kg}, 20 \%$ solution; Sigma) by intraperitoneal injection. A hole was drilled in the skull in correspondence with the binocular portion of the primary visual cortex (binocular area 17 or area $\mathrm{OC} 1 \mathrm{~B}$; Fig. 1). In the rat, $\mathrm{OC} 1 \mathrm{~B}$ corresponds to the lateral portion of the primary visual cortex (stereotaxic coordinates $>4 \mathrm{~mm}$ from the central fissure) mapping the upper nasal visual field (Fig. 1). It is well characterized by the use of several anatomical markers (Zilles et al., 1984), and according to 14-deoxyglucose autoradiographies (Thurlow and Cooper, 1988), it is divided into a large, more medial portion where alternate patches of stronger and weaker contralateral input are present, and a small, more lateral zone predominantly activated by contralateral input. After exposure of the brain surface, the dura was removed and a micropipette filled with $\mathrm{NaCl}(3 \mathrm{M})$ was inserted into the cortex. The cortical surface 

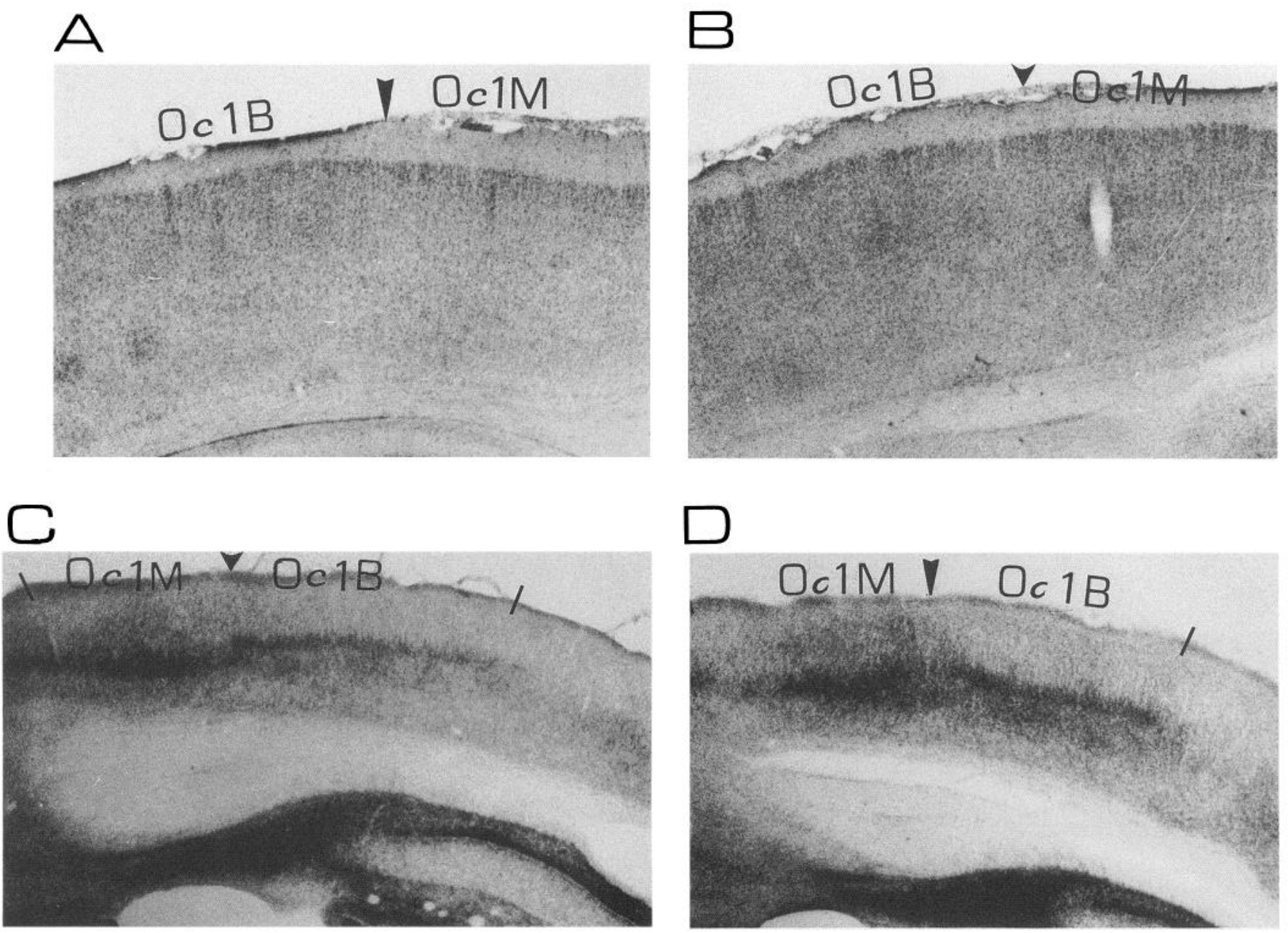

Figure 2. Nissl- $(A$ and $B)$ and AChE- $(C$ and $D)$ stained coronal sections cut at the level of the visual cortex of normals rats $(A$ and $C)$ and of NGF-treated rats $(B$ and $D)$. In Nissl- and AChE-stained sections, the arrowheads delimitate subfields OC1M and OC1B according to the atlas of rat brain (Paxinos and Watson, 1986). In AChE-stained sections, the primary visual cortex OCl is intensely stained. In the subfield OC1M the stain is higher in the middle-deep layers, while in area OC1B AChE reaction is more evident in middle-superficial layers. Scale: $A$ and $B, 1 \mathrm{~cm}=$ $360 \mu \mathrm{m} ; C$ and $D, 1 \mathrm{~cm}=570 \mu \mathrm{m}$.

was then protected from drying with agar (1.5 gm in saline, $60 \mathrm{ml})$. To prevent sampling biases, due to the organization of area OC1B with respect to the ocular dominance, our penetrations were angled (i.e., nonperpendicular to the cortical surface) and for each animal at least two well-spaced penetrations were performed. The last penetration was marked by lesions made by passing a small current $(10 \mu \mathrm{A}, 10 \mathrm{sec})$ every $250 \mu \mathrm{m}$ during electrode withdrawal for subsequent track reconstruction.

Both eyes were fixed and kept open by means of adjustable metal rings (Parnavelas et al., 1981) surrounding the external portion of the eye bulbs, and the cornea was protected with artificial tears (Lacrinorm, Farmigea, Pisa, Italy). With this restraint, the stability of the eyes is good. Pupils were left undilated since it proved extremely difficult to provide artificial pupils that would not cause vignetting, as observed by Lennie and Perry (1981). With dilated pupils and without artificial pupils, the quality of the eye optics would be extremely poor, and in addition, glare would probably occur. Given the impossibility of backprojecting the optic disk with natural pupils $(0.5-1 \mathrm{~mm}$ in diameter with the luminances we used), we dilated the pupil (atropine sulfate, $0.1 \%$ ) at the end of the experiment. The position of the optic disk was marked onto a tangent screen where all the cell receptive fields position had been plotted (Lennie and Perry, 1981).

Body temperature was continuously monitored and maintained around $38^{\circ} \mathrm{C}$ by means of a thermostatted electric blanket. Electrocardiogram was also continuously monitored.

The visual stimuli were hand-moved light bars projected on a reflecting tangent screen or gratings or bars computer generated on a display
(HP1300A, $28 \times 22 \mathrm{~cm}$; mean luminance, $12 \mathrm{~cd} / \mathrm{m}^{2}$ ). Both the screen and the display were $20 \mathrm{~cm}$ from the rat eyes.

On isolating a cell, the following experimental protocol was followed.

(1) The location of the receptive field in visual space, and the optimal stimulus orientation and direction of movement were determined with hand-held stimuli. Only cells with receptive fields farther than $30^{\circ}$ nasal from the optic disk and in the upper visual field were included in our sample. We took care that cells were sampled at comparable eccentricities in the different experimental groups. In the rat, the vertical meridian is estimated to be around $55-58^{\circ}$ from the projection of the optic disk (Montero et al., 1968; Hughes, 1979; Reese and Jeffery, 1983; Reese, 1988). The estimated mean receptive fields eccentricities from the vertical meridian in the different experimental groups were $13 \pm 9^{\circ}$ in normal rats $(N=164), 11 \pm 8^{\circ}$ in MD rats $(N=112), 12 \pm 9^{\circ}$ in $\mathrm{MD}+\mathrm{NGF}$ rats $(N=119)$, and $14 \pm 8^{\circ}$ in MD cytochrome C-treated rats $(N=50)$.

(2) Neurons in ocular dominance class 1 were defined as being driven only by the stimulation of the contralateral eye; neurons in ocular dominance classes 2 and 3 were binocular and preferentially driven by the contralateral eye; neurons in ocular dominance class 4 were equally driven by the two eyes; neurons in ocular dominance classes 5 and 6 were binocular and preferentially driven by the ipsilateral eye; and neurons in ocular dominance class 7 were driven only by the ipsilateral eye. The category labeled NC contains those neurons that could not be classified using visual stimuli.

(3) Receptive field type and cell responsiveness were assessed with bars or gratings of optimal orientation according to standard criteria 


\begin{tabular}{|c|c|c|c|}
\hline & P19 & P27 & P45 to adult \\
\hline RF size (degrees) & $35 \pm 6$ & $16 \pm 7$ & $6 \pm 1$ \\
\hline NO cells & $98 \%$ & $35 \%$ & $25 \%$ \\
\hline Binocular cells & $92 \%$ & $79 \%$ & $80 \%$ \\
\hline Class 4 cells & $50 \%$ & $20 \%$ & $23 \%$ \\
\hline Class $1-3$ cells & $46 \%$ & $65 \%$ & $66 \%$ \\
\hline
\end{tabular}

Data show receptive field (RF) size, percentages of nonorientational (NO) cells and percentages of binocular, ocular dominance class 4 , and ocular dominance classes 1, 2, or 3 cells in rats of different ages (P19, P27, and older than P45). Cell sample size: $N=15$ for RF at all ages; NO cells, $N=50$ at P19, $N=57$ at P27 and $N=168$ at P45 to adult; ocular dominance, $N=50$ at $\mathrm{P} 19, N=50$ at P27, and $N=164$ at P45 to adult. Significance of differences between groups: RF size (two-tailed $t$ test): P19-P27, $p \ll 0.001$; P19-adult, $p \ll 0.001 ;$ P27-adult, $p \ll$ 0.001 . NO cells (test for binomial distribution): P19-P27, $p \ll 0.00003$; P19adult, $p \ll 0.00003 ;$ P27-adult, NS. Ocular dominance distribution $\left(\chi^{2}, 4 \mathrm{df}\right.$ ) P19-P27, $p<0.005$; P19-adult, $p<0.02$; P27-adult, NS. Binocular cells (test for binomial distribution): P19-adult, $p<0.02$; P19-P27, $p<0.02$. Class 4 cells: P19-adult, $p<0.0001$. Class $1-3$ cells: P19-adult, $p<0.005$.

(Hubel and Wiesel, 1962; Burne et al., 1984). Orientation selectivity was determined with bars or gratings (contrast, 30-40\%). Neurons were classified as orientational if the cell response was maximal for a given stimulus orientation (preferred orientation) and indistinguishable from spontaneous activity for at least the orthogonal stimulus orientation; cells were classified as biased if the response was present at all orientations but clearly greater $(>2 \times)$ for ccrtain oricntations than for othcrs; cells were classified as nonorientational if the response was of comparable strength on six orientations (vertical, horizontal, $+30^{\circ}$, and $+60^{\circ}$ ). Examples of orientational tuning curves for each category are reported in Figure $6 \mathrm{~A}$. For each orientation, the cell response was computer averaged over at least 20 stimulus cycles. The response amplitude was taken as the peak amplitude (response to a bar) or as the amplitude of modulation (response to a grating).

The average spontaneous discharge was determined by recording the cell firing rate for 1-2 min in the absence of any patterned visual stimulus.

At the end of the experiment, animals were perfused with normal saline followed by $4 \%$ paraformaldehyde (Riedle, D) in $0.1 \mathrm{M}$ phosphate buffer. The brains were coronally sectioned (Vibratome, series 1000) and stained with cresyl violet. The sitc of injection was cxamincd for possible damage. We found that the injected ventricles were not dilated with respect to the other side or to controls. We did not find alterations of cerebral structures in NGF-treated animals. In particular, no difference was noted in the morphology of the LGN (not shown) and of the visual cortices (Fig. $2 A, B$ ) between NGF-treated and control animals. The pattern of acetylcholinesterase (histochemical reaction protocol according to Bear et al., 1985), which is a typical marker of the architecture of the rat visual cortex (Zilles et al., 1984), was also normal in NGFtreated rats (Fig. $2 C, D$ ).

Statistical analysis. The following types of statistical analysis have been performed to evaluate the significance of differences between data obtained for different groups: $\chi^{2}$ test $(4 \mathrm{df})$ for the difference between ocular dominance distributions, analysis of variance and two-tailed $t$ test for the difference between mean values, and the variance of the binomial distribution for differences between percentages. A difference was considered significant if its probability $p$ was less than 0.05 . To test whether the data obtained within the same group were consistent with having been sampled from a common parent distribution, the Kolmogorov-Smirnov (K-S) statistic has been applied (Lindgren, 1960 Edwards, 1961).

\section{Results}

Ocular dominance distribution and receptive field properties in the binocular portion of the rat primary visual cortex

In the pigmented rat, the binocular portion of each visual hemifield extends approximately $40^{\circ}$ from the vertical meridian, in the upper visual field (Hughes, 1979). The corresponding bin-

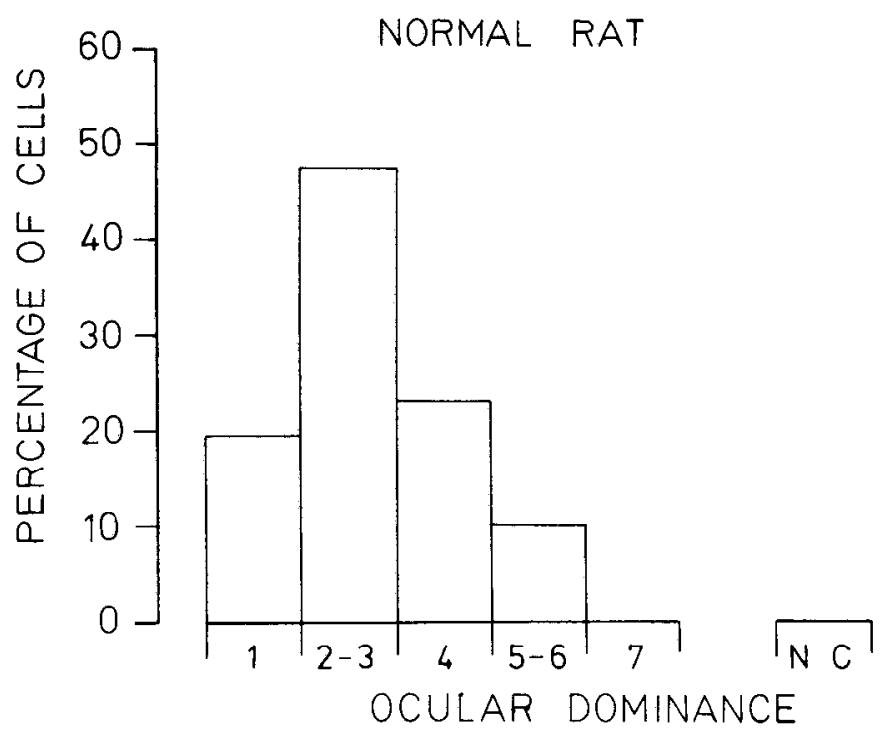

Figure 3. Ocular dominance distribution for visual cortical neurons (area 17) in normal rats ( 164 cells). Neurons in ocular dominance class 1 were driven only by the stimulation of the contralateral eye; neurons in ocular dominance classes 2 and 3 were binocular and preferentially driven by the contralateral eye; neurons in ocular dominance class 4 were equally driven by the two eyes; neurons in ocular dominance classes 5 and 6 were binocular and preferentially driven by the ipsilateral eye; and neurons in ocular dominance class 7 were driven only by the ipsilateral eye. The category labeled NC contains those neurons that could not be classified using visual stimuli.

ocular portion of the primary visual cortex is binocular area 17 or OC1B (see Fig. 1).

We have recorded 170 cells from area OC1B in normal adult rats within $30^{\circ}$ from the vertical meridian (mean eccentricity of the receptive fields centers $=13 \pm 9^{\circ}$ ). For each cell, the receptive field properties and the ocular dominance were assessed. As demonstrated by Burne et al. (1984) and Parnavelas et al. (1981), the properties of neurons in rat primary visual cortex are comparable to those found in higher mammals' visual cortex (cats and monkeys). Receptive fields are well defined and structured, cells can be classified as simple-like or complex-like, and the great majority of the cells are orientation selective. We have confirmed these observations (Table 1; see also Fig. 6).

Ocular dominance was expressed according to the Hubel and Wiesel classification. Cells in ocular dominance class 1 and 7 are exclusively responsive to the contralateral or ipsilateral eye, respectively. Cells in ocular dominance class 4 are equally dominated by both eyes, cells in ocular dominance classes 2 and 3 are dominated by the contralateral eye, and cells in class 5 and 6 are dominated by the ipsilateral eye.

The ocular dominance distribution normally found in adult rats (older than P45) is illustrated in Figure 3. This is the cumulative distribution obtained from recordings in seven rats. A few remarks have to be made.

(1) There was a clear dominance of the input from the contralateral eye (contralateral bias): $47 \%$ of the cells fell in class 2 or 3 and $19 \%$ in class 1 . This contralatcral bias (also present in cat visual cortex but less pronounced) reflects the predominance of the crossed versus the uncrossed visual input to each hemisphere, which in the rat is quite strong (Polyak, 1957).

(2) In spite of the small size of the contingent of uncrossed optic fibers, the percentage of binocular cells (classes 2-6) is quite high ( $80 \%$ in the total distribution) and comparable to 


\begin{tabular}{|c|c|c|c|c|}
\hline Treatment & Rat & $\begin{array}{l}\text { Ipsilateral } \\
\text { index }\end{array}$ & $\begin{array}{l}\text { Binocular } \\
\text { index }\end{array}$ & Cells \\
\hline \multirow[t]{7}{*}{ None } & NOR1 & 0.06 & 0.69 & 16 \\
\hline & NOR2 & 0.05 & 0.84 & 37 \\
\hline & NOR3 & 0.11 & 0.83 & 18 \\
\hline & NOR4 & 0.16 & 0.89 & 19 \\
\hline & NOR5 & 0.17 & 0.83 & 23 \\
\hline & NOR6 & 0.10 & 0.70 & 20 \\
\hline & NOR7 & 0.13 & 0.77 & 31 \\
\hline \multirow[t]{5}{*}{ MD } & MD1 & 0.97 & 0.13 & 31 \\
\hline & MD2 & 0.93 & 0.28 & 14 \\
\hline & MD3 & 0.56 & 0.28 & 18 \\
\hline & MD4 & 0.77 & 0.53 & 17 \\
\hline & MD7 & 0.89 & 0.44 & 18 \\
\hline \multirow[t]{6}{*}{$\mathrm{MD} \mid \mathrm{NGF}$} & NGF1 & 0.0 & 0.96 & 25 \\
\hline & NGF2 & 0.0 & 0.75 & 12 \\
\hline & NGF3 & 0.16 & 0.91 & 32 \\
\hline & NGF5 & 0.35 & 0.95 & 20 \\
\hline & NGF6 & 0.31 & 0.92 & 13 \\
\hline & NGF8 & 0.13 & 0.80 & 15 \\
\hline \multirow[t]{3}{*}{$\mathrm{MD}+\mathrm{CIT}$} & CIT1 & 0.83 & 0.42 & 12 \\
\hline & CIT2 & 0.68 & 0.36 & 22 \\
\hline & CIT3 & 0.69 & 0.37 & 16 \\
\hline
\end{tabular}

Data for the MD, NGF, and MD+CIT (monocular deprivation combined with intraventricular cytochrome $\mathrm{C}$ injection) animals come from the cortex contralateral to the deprived eye. Ipsilateral index $=($ cells in classes 5-7)/(total number of responsive cells); binocular index $=$ (cells in classes $2-6) /($ total number of responsive cells). The last column shows the number of responsive cells recorded; only data for those animals where more than 10 responsive cells had been recorded are reported in this table. Significance of differences between groups (two-tailed $t$ test) were, for ipsilateral index: None-MD, $p \ll 0.001$; MD-NGF, $p \ll 0.001$; None-NGF, NS; None-CIT, $p \ll 0.001$; CIT-MD, NS; CIT-NGF, $p \ll 0.001$; for binocular index: None-MD, $p \ll 0.001 ;$ MD-NGF, $p \ll 0.001$; None-NGF, NS; None-CIT, $p \ll 0.001 ;$ CIT-MD, NS; CIT-NGF, $p \ll 0.001$.

that found in cats (Hubel and Wiesel, 1962) and monkeys (Baker et al., 1974).

Results from recordings in single animals are reported in Table 2. Here, two indexes summarizing the ocular dominance distribution are reported, the binocular index (number of cells in classes 2-6 || total number of cells) and the ipsilateral input index (number of cells in classes 5-7 $\|$ total number of cells). There is a certain degree of interindividual variability, but for each index the data are consistent with the hypothesis that they were all sampled from the same parent distribution (K-S test, $6 \mathrm{df}, p>0.20$ ).

To test whether the ocular dominance distribution found in adult rats emerges gradually during the first weeks of postnatal development, as it does in other mammals (Hubel and Wiesel, 1963; Blakemore and Van Sluyters, 1975; Albus and Wolf, 1984), we have recorded six normal rats at two stages of postnatal development, P19 $(N=3)$ and P27 $(N=3)$ (Table 1). In both cases, the centers of the receptive fields (although of difficult determination in the youngest animals given their large dimensions) were of comparable eccentricities with those recorded in the adult. At P19 (Table 1, first column), most cortical cells were binocular $(92 \%)$ and $50 \%$ were equally dominated by both eyes (class 4). By P27, class 4 cells amounted to $26 \%$ (Table 1 , second column) and the ocular dominance distribution was not

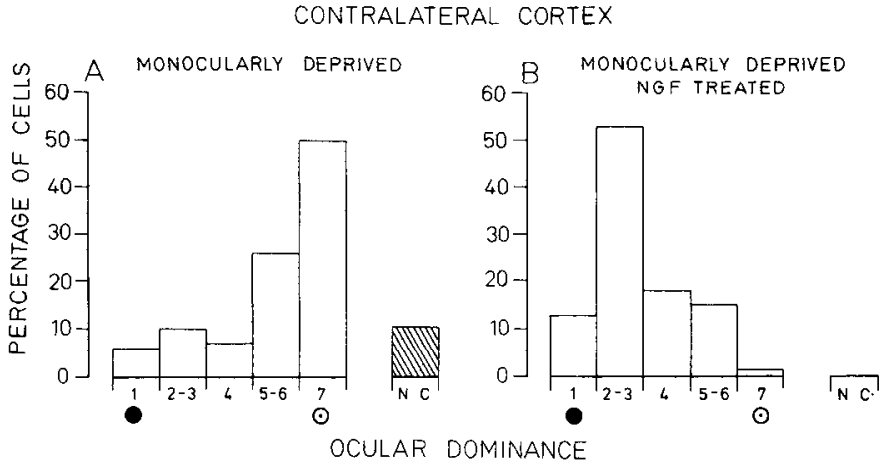

Figure 4. Ocular dominance distribution of visual cortical neurons recorded in area 17 contralateral to the deprived eye. $A$, Data from eight untreated MD rats (125 cells, $13 \mathrm{NC}$ ). $B$, Data from seven MD rats treated with NGF (119 cells, all responsive). $\bullet$, deprived eye; $\odot$, nondeprived eye. The ocular dominance distribution for untreated MD rats is significantly different both from the distribution in normal rats ( $p \ll$ 0.001 ) and from the distribution in MD rats treated with NGF ( $p \ll$ $0.001)$. The ocular dominance distribution for MD NGF-treated rats does not significantly differ from the distribution in normal rats.

significantly different from the adult. Within the same period, other properties of visual cortical cells mature. At P19, the vast majority of cortical cells (50 of 51) were already visually responsive, and the quality of the visual response (vigor, reliability, briskness) progressed rapidly from P19 to P27. It has to be noted that at $\mathrm{P} 19$ cells showed clear adaptation. Receptive field size, which was nearly as large as the entire binocular hemifield $\left(35 \pm 6^{\circ}\right)$ at $\mathrm{P} 19$ (Table 1) was down to $16 \pm 7^{\circ}$ by $P 27$, a value still significantly larger than in the adult $\left(6 \pm 1^{\circ}\right)$. Nonorientational cells, which were the overwhelming majority at $\mathrm{P} 19(98 \%)$, decreased to $35 \%$ at $\mathrm{P} 27$, a fraction very close to the adult value ( $25 \%$; Table 1$)$.

\section{Ocular dominance distribution in MD rats and effects of NGF treatment}

In all our MD rats, the duration of the deprivation was 1 month or more. Judging from the existing anatomical and behavioral data (Rothblat et al., 1978; Rothblat and Schwartz, 1979; Stafford, 1984), the presumed critical period for the effects of monocular deprivation in the rat does not extend beyond $\mathrm{P} 40$. We have confirmed this observation: monocular deprivations starting after $\mathrm{P} 40$ did not affect the visual acuity of the deprived eye (L. Maffei, N. Berardi, L. Domenici, V. Parisi, and T. Pizzorusso, unpublished observations). One month of monocular deprivation should therefore span most of the critical period. It has to be noted that the relatively brief duration of the critical period in the rat is an advantage in pharmacological studies, reducing the period of treatment.

The effects of monocular deprivation on the ocular dominance distribution were first assessed in the visual cortex contralateral to the deprived eye. As shown in Figure 4A, the ocular dominance distribution in area 17 is dramatically altered by monocular deprivation [cumulative data from all eight MD rats: 125 cells recorded, 13 nonresponsive (10\%), 112 responsive; mean eccentricity of the receptive field centers $\left.=11 \pm 8^{\circ}\right]$. The percentage of binocular cells is reduced from $80 \%$ to $40 \%$. The contralateral, deprived eye dominates only $16 \%$ of cortical cells, and the ipsilateral, nondeprived eye now dominates, exclusively or predominantly, $75 \%$ of the cells. The difference with the normal ocular dominance distribution is highly significant $(p<$ 


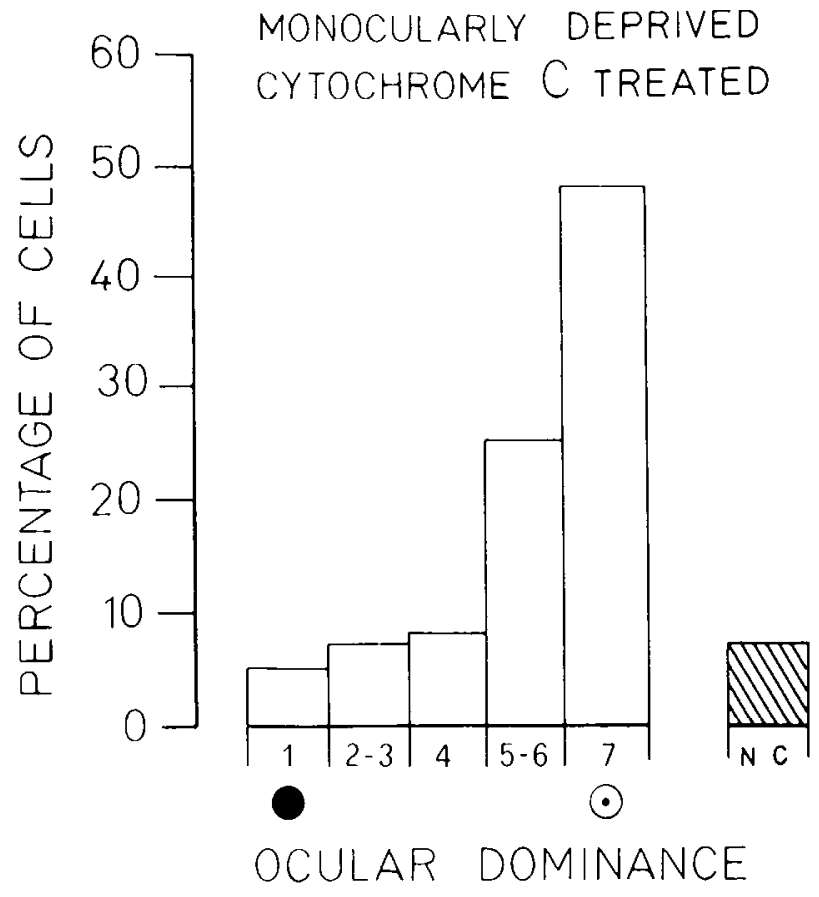

Figure 5. Ocular dominance distribution for visual cortical cells recorded in area 17 contralateral to the deprived eye in MD rats treated with cytochrome C ( 54 cells. 4 NC). Other conventions are as in Figure 3. The difference between the ocular dominance distributions in normal and in MD NGF-treated rats is highly significant $(p \ll 0.001)$. The difference in the distribution found in untreated MD rats is not significant.

$\left.0.001, \chi^{2}\right)$. Data from recordings in single MD rats are reported in Table 2 . There are interindividual variations, but the shift toward the dominance of the ipsilateral. nondeprived eye and the strong reduction in binocular cells are present in all animals. For each index. the data from single animals are consistent with the hypothesis that they had all been sampled from the same parent distribution (K-S test. $4 \mathrm{df} . p>0.20$ ). The two-tailed $t$ test (ANOVA for the difference between means for two groups) for the MD group and the normal group shows that the interindividual variability within groups is much smaller than the intergroup variability and that the mean values for the ipsilateral and binocular indexes for MD rats are significantly different from the corresponding values in normal rats $(p \ll 0.001)$.

The results obtained in those MD rats that received NGF throughout the deprivation period are reported in Figure $4 B$ ( 119 cells recorded in 7 animals, all 119 responsive; mean eccentricity of receptive fields centers $=12 \pm 9^{\circ}$ ). It is evident from the figure that in this case monocular deprivation caused no change in the ocular dominance distribution. Indeed, the distribution obtained in MD NGF-treated rats was not significantly different from the distribution in normal rats $(p>0.05)$, while being significantly different from the distribution in MD rats $(p<0.001)$. The percentage of binocular cells is $86 \%$, and the contralateral deprived eye dominates $66 \%$ of the cells. Note also that no unresponsive cell was found (unlike untreated MD rats). Data from recordings in single MD NGF-treated rats are reported in Table 2 . There is some interindividual variability, but it is evident that NGF was effective in counteracting the effects of monocular deprivation in all animals. The data for single animals are consistent with the hypothesis that they had all been sampled from a common parent distribution for the binocular index but not for the ipsilateral index. (K-S test. $5 \mathrm{df}$ : $0.05>p>0.01$ for the ipsilateral index; $p>0.20$ for the binocular index). The two-tailed $t$ test for the MD+NGF, the $\mathrm{MD}$, and the normal rats group shows that the mean binocular and ipsilateral indexes for the MD+NGF group are not significantly different from the corresponding values in normal rats. while being so with respect to those obtained in untreated MD rats $(p \ll 0.001)$. An ANOVA across the three groups (normal. $\mathrm{MD}, \mathrm{MD}+\mathrm{NGF}$ ) confirms that the means are not homogeneous and shows that the intergroup variability is larger than the variability within groups $[F(2.15)=5.3$ for the ipsilateral index and 5.44 for the binocular index: $p<0.05$ in both cascs]. We then applied Tukey's procedure (Edwards, 1961) to classify the means into groups that are alike among themselves but differ from each other. The result of this test is that, for both indexes, normal and $M D+N G F$ rats form one group and MD rats form a different group.

We conclude that MD causes a dramatic shift in the ocular dominance distribution and that NGF treatment is very effective in counteracting MD effects.

To control for possible aspecific effects of NGF treatment. we determined the ocular dominance distribution in three MD rats treated with cytochrome $\mathrm{C}$, a molecule that is generally used to control for NGF treatment (Hendry, 1989). The results from these rats, shown in Figure 5 (54 cells. 50 responsive: mean eccentricity of receptive fields centers $=14 \pm 8^{\circ}$ ) and Table 2 , clearly indicate that cytochrome $C$ treatment was completely ineffective in preventing the effects of monocular deprivation. The ocular dominance distribution from cytochrome $\mathrm{C}$-treated rats is indistinguishable from that obtained in MD rats.

The ANOVA for all four groups shows again that there are different populations and that the intergroup variability is greater than the variability within groups $[F(3.17)=8.15$ for the ipsilateral index and 37.95 for the binocular index; $p<0.01$ in both cases]. Normal rats and $\mathrm{MD}+\mathrm{NGF}$ rats form one group: $\mathrm{MD}$ rats and cytochrome $\mathrm{C}$ rats form a different group.

\section{Ipsilateral cortex}

Recordings have also been made in the cortex insilateral to the deprived eye in MD rats untreated (52 cells, 3 rats) and NGF treated ( 50 cells, 3 rats). The results indicate that monocular deprivation effects are stronger in the ipsilateral than in the contralateral cortex. Only $15 \%$ of the cells are binocular, and all of them are dominated by the nondeprived eyc (both values are significantly different from the corresponding ones in normal and NGF-treated rats, $p \ll 0.0001$ ). In NGF-treated rats, monocular deprivation was much less effective: $75 \%$ of the cells are binocular. a value not significantly different from normal, although the dominance of the contralateral nondeprived eye is significantly stronger than normal $(86 \%$ cells in classes $1-3$ vs $66 \%, p<0.004)$.

\section{Functional properties of cortical cells in NGF-treated rats}

An important point was to control whether NGF treatment affected the functional properties of visual cortical cells.

\section{Spontaneous discharge}

First of all, we tried to assess possible effects of NGF on the spontaneous activity of cortical cells. In NGF-treated rats, recorded 3 or more days after the end of the treatment. the mean spontaneous activity resulted $9 \pm 6$ spikes sec (three animals, $N=22$ ). This value is not significantly different from the mean 

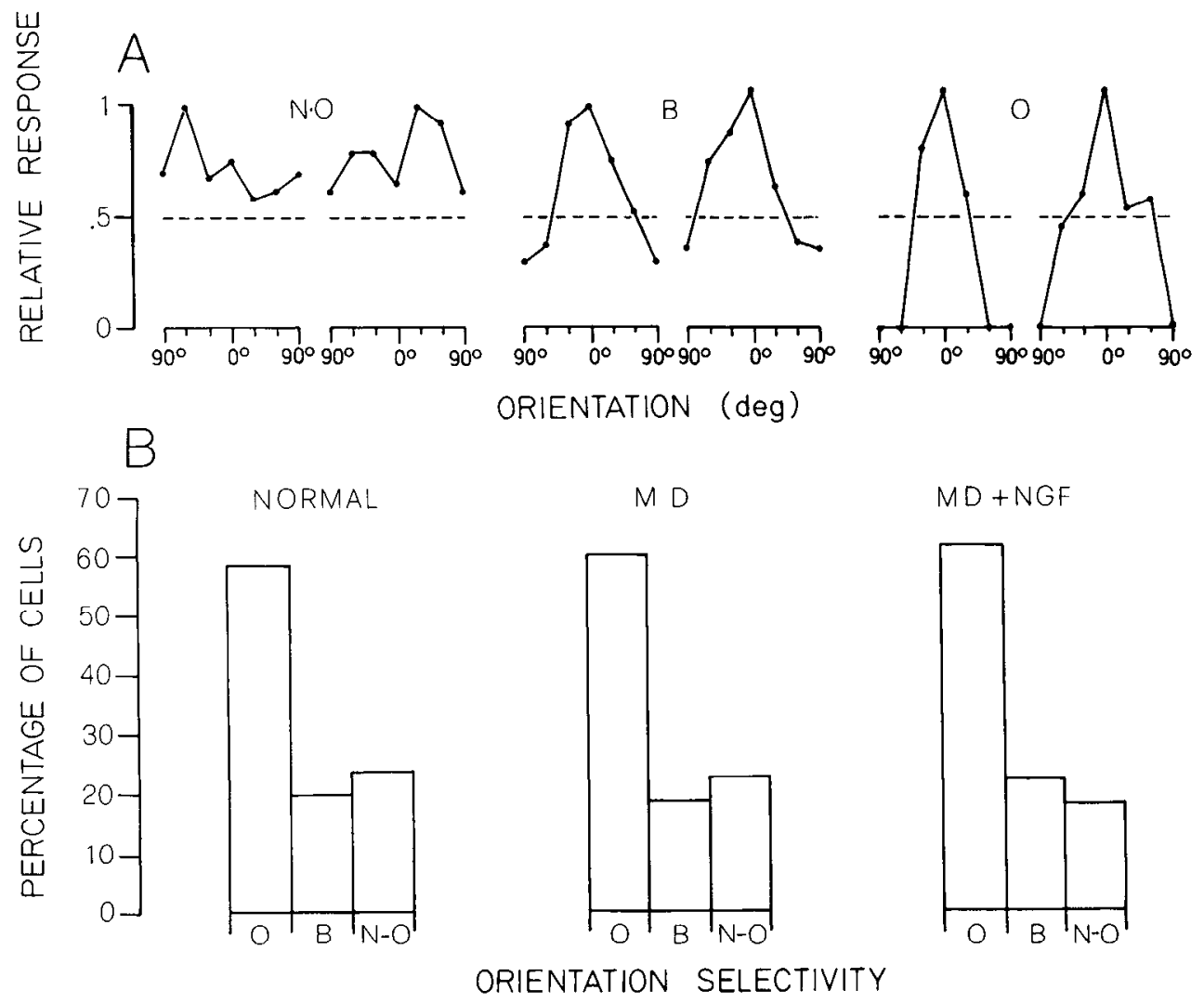

Figure 6. Orientation selectivity of cells in the rat primary visual cortex. Neurons were classified as orientational $(O)$ if the cell response was maximal for a given stimulus orientation (preferred orientation) and indistinguishable from spontaneous activity for at least the orthogonal stimulus orientation; cells were classified as biased $(B)$ if the response was present at all orientations but clearly greater $(>2 \times)$ for certain orientations than for others; cells were classified as nonorientational $(\mathrm{N}-\mathrm{O})$ if the response was of comparable strength on six orientations (vertical and horizontal, $+30^{\circ}$ and $+60^{\circ}$ ). $A$, Examples of orientational tuning curves for each category. The cell relative response amplitude $(1=$ strongest response) is plotted as a function of the stimulus orientation. Points on the abscissa correspond to responses indistinguishable from the spontaneous activity. $O^{\circ}$ is the preferred orientation for $O$ and $B$ cells, and is the vertical orientation for $N-O$ cells. Clockwise and anticlockwise rotations from $0^{\circ}$ are represented on the right and left abscissas, respectively, in steps of $30^{\circ}$. For each orientation, the cell response was computer averaged over at least 20 stimulus cycles. $B$, Histograms compiled from neurons recorded in the primary visual cortex of normal, MD, and MD+NGF rats and classified according to their orientation selectivity. The total number of cells recorded is $N=164$ for normal rats, $N=184$ for MD rats, and $N=186$ for $\mathrm{MD}+\mathrm{NGF}$ rats (data for the ipsilateral and contralateral cortex are pooled together). The differences between the distributions in normal, $\mathrm{MD}$, and $\mathrm{MD}+\mathrm{NGF}$ rats are not significant.

spontaneous discharge in normal rats (three animals, $N=24$; mean $=10 \pm 5$ spikes/sec), suggesting that there are no longterm effects of NGF on spontaneous activity. To control for possible transient effects of NGF on spontaneous activity, the spontaneous discharge of $\mathrm{H} 20$ cells was recorded in two rats (P42) $4 \mathrm{hr}$ after the last NGF injection in the treatment. The mean spontaneous activity resulted in $8 \pm 6$ spikes/sec. This value is also not significantly different from the normal spontaneous activity, suggesting that there are no short-term effects of NGF on this parameter.

\section{Orientation selectivity}

We then controlled for whether NGF treatment had affected the orientation selectivity of visual cortical cells. Figure $6 A$ reports examples of orientational tuning curves for two orientational (O), two biased (B), and two nonorientational (N-O) cells. For the orientational cells, one of the most selective (bandwidth, $\sim 70^{\circ}$ ) and one of the least selective (bandwidth, $\sim 100-110^{\circ}$ ) are reported. On average, the mean tuning for orientational cells in our sample was $80-90^{\circ}$. In Figure $6 B$, we have reported the percentage of cells recorded in normal, $\mathrm{MD}$, and $\mathrm{MD}+\mathrm{NGF}$ rats classified, according to their orientation selectivity, as or- ientational $(\mathrm{O})$, biased (B), and nonorientational (N-O) (see Materials and Methods). Two points should be made. First, the orientation selectivity for cells recorded in NGF-treated rats was significantly higher than in P19 rats (Table 1), suggesting that NGF did not block the development of the functional properties of visual cortical cells. Second, the orientation selectivity in NGF-treated rats was not significantly different from normal rats, suggesting not only that the visual cortex has developed but that it has developed normally. This is well in accordance with the fact that no gross differences in cell responsiveness and receptive field size and organization were noted in NGF-treated rats compared with normal rats.

An interesting result emerged when the orientation selectivity distributions for untreated MD rats and NGF-treated MD rats were examined separately for cells dominated by the deprived eye and the nondeprived eye. This was done only for the contralateral cortex, since class 5-7 cells are missing in the ipsilateral cortex of untreated MD rats. The result of this analysis is shown in Figure 7. In untreated MD rats, the few cells dominated by the deprived eye $(N=20)$ are less orientational than those dominated by the nondeprived eye $(N=84)$. In the first case, cells classified as orientational or biased were 13 of $20(65 \%)$; 


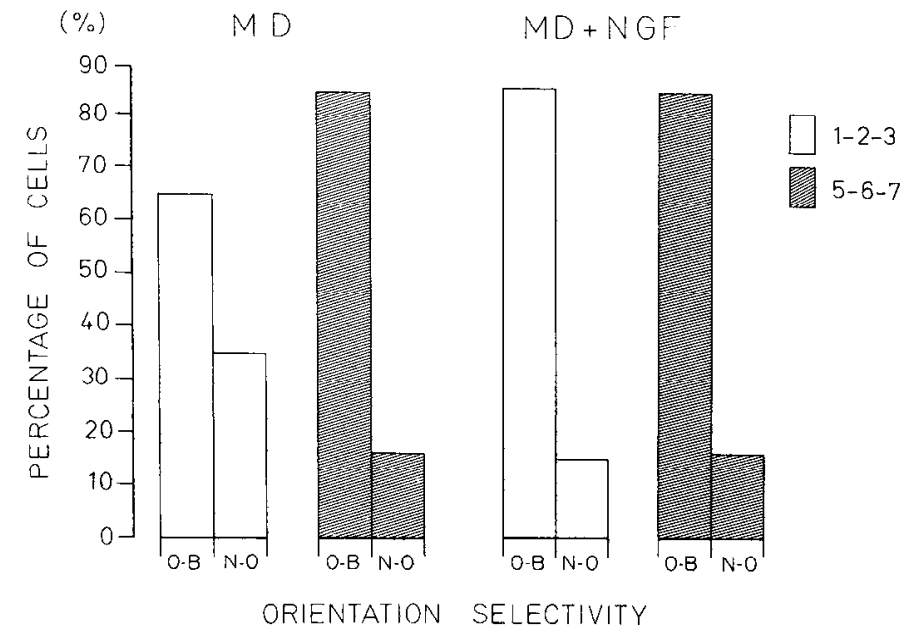

Figure 7. Histograms compiled from neurons recorded in the primary visual cortex contralateral to the deprived eye for untreated MD rats and MD+NGF rats. Cclls werc divided into two groups, contralaterally dominated (classes $1-2-3$, open columns) and ipsilaterally dominated (classes 5-6-7, shaded columns) and then classified according to their orientation selectivity. Orientational $(O)$ and biased $(B)$ cells have been grouped together. The difference between the percentage of orientational-biased cells dominated by the deprived and nondeprived eye, respectively, is significant for the MD group $(p<0.05)$.

in the second case, they were 71 of $84(84.5 \%)$. The difference is significant $(p<0.05)$. This is not the case for NGF-treated MD rats, where the two distributions are almost identical.

\section{Functional properties of visual cortical cells in NGF-treated rats recorded during the critical period}

It might be argued that NGF could have transiently affected the functional properties of visual cortical cells during the critical period, due to their possible higher sensitivity to the trophic factor. To control for this, we have recorded four rats under NGF treatment at two stages of the critical period, $\mathrm{P} 19(N=2)$ and P27 $(N=2)$ and compared the results with those obtained in normal rats of the same age. Recordings began $1 \mathrm{hr}$ after the last NGF injection.

At $\mathrm{P} 19$, all cells were visually responsive in NGF-treated rats, and their response quality was comparable to that in normal rats. The mean spontaneous discharge was $4 \pm 5$ spikes/sec $(N$ $=56$; median, 2 spikes $/ \mathrm{sec}$; interquartile range, $0.5-7$ spikes/ sec) in normal rats and $4 \pm 5$ spikes/sec $(N=51)$ in NGFtreated rats (median, 2.5 spikes/sec; interquartile range, 0.50-7 spikes/sec). The distributions being skewed (due to the zero inferior limit), we have performed, in addition to the $t$ test for the difference between the mean values, a $t$ test on the difference between the mean values of the logarithmic transform of the data and a $\chi^{2}$ test for the difference between the distributions. All differences were nonsignificant. Orientation selectivity is a property not yet well developed in our sample of normal P19 rats (Table 1), and this was the case also for P19 NGF-treated rats.

At $\mathrm{P} 27$, all cells were visually responsive in the NGF-treated rats, and their response quality was comparable to that in normal rats of the same age. The spontaneous discharge was $4 \pm 6$ spikes/sec $(N=61)$ in normal rats (median, 2 spikes/sec; interquartile range, $0.5-5$ spikes $/ \mathrm{sec})$ and $5 \pm 6$ spikes $/ \mathrm{sec}(N=42)$ in NGF-treated rats (median, 3 spikes/sec; interquartile range, 0.5-6 spikes/sec). Also in this case, the distributions are skewed, and in addition to the $t$ test for the difference between the mean values, a $t$ test on the difference between the mean values of the logarithmic transform of the data and a $\chi^{2}$ test for the difference between the distributions have been performed. All differences are nonsignificant. In normal P27 rats, only 37\% of visual cortical cells are nonorientational (Table 1). The percentage of nonorientational cells in NGF-treated rats (17 of $42,40 \%)$ is not significantly different from the normal value. We conclude that NGF treatment did not affect the functional properties of visual cortical cells tested during the critical period.

\section{Discussion}

The visual cortex of the rat: a suitable experimental model for neural plasticity studies

The modifications induced by early sensory deprivations in the functional organization of the sensory cortices are a good model to study the activity-dependent strengthening of synapses in mammals. In the rat, this has been done for the barrel field in the somatosensory cortex (Simons and Land, 1987) and in the acoustic system (Sanes and Constantine-Paton, 1983).

Our results extend those already present in the literature (Fifkova, 1968; Rothblat et al., 1978; Rothblat and Schwartz, 1979; Stafford, 1984; Dean, 1990) in indicating that the rat visual cortex is a suitable model to study neural plasticity and that the paradigm of monocular deprivation, widely exploited to study visual cortical plasticity in other mammals, can be successfully used. Indeed, neurons in the rat primary visual cortex have welldefined functional properties and are distributed in different classes of ocular dominance with a high proportion of binocular cells, comparable to that in cats and monkeys (Hubel and Wiesel, 1962; Baker et al., 1974). Both the ocular dominance distribution and the functional properties of cortical cells develop gradually during the first month of postnatal development. In the rat, there is no clear anatomical demonstration of ocular dominance column. However, Thurlow and Cooper (1988) have reported alternate patches of stronger and weaker contralateral input to $\mathrm{OC} 1 \mathrm{~B}$ using ${ }^{14} \mathrm{C}$ deoxyglucose.

Our results show that the effects of monocular deprivation on the ocular dominance distribution arc robust. Binocularity is decreased and the percentage of cells dominated by the deprived eye falls dramatically, even when the deprived eye is the normally dominant contralateral eye. Similar results had been obtained by Dräger (1978) in the mouse. The anatomical correlate of monocular deprivation at cortical level is the change in the number of cortical dendritic spines observed by Rothblat and Schwartz (1979). We have also reported that monocular deprivation, as it is the case for other mammals, induces in the rat shrinkage of cell bodies in the deprived laminae of the LGN (Domenici et al., 1991b).

\section{Specificity of NGF effects}

The main result of this work is that NGF treatment prevents the shift in ocular dominance induced by monocular deprivation spanning the whole presumed rat critical period.

The following observations seem to suggest that the effects of NGF are neither pathological in nature nor unspecific.

(1) The absence of any gross behavioral effects in experimental animals following intraventricular injections of NGF seems to exclude general pathological alterations. This is further supported by behavioral experiments in MD NGF-treated kittens: in these animals, the behavior was normal, the performance in 
the jumping stand was undistinguishable from that of control kittens, and the visual acuity of the deprived eye was normal (Maffei et al., in press).

(2) The results obtained in control animals (cytochrome C treated) indicate that NGF effects are not due to the treatment per se (resulting, e.g., from repeated anesthesia). Unspecific NGF effects are also excluded by our previous findings that local applications of NGF onto one visual cortex prevents the amblyopic effects of monocular deprivation only in the treated hemisphere (Domenici et al., 1991a). This last finding suggests that the action of NGF occurs within the visual cortex and/or its afferent systems.

(3) Intraventricular transplant of hybridoma cells producing anti-NGF antibodies causes a decrease in the number of cortical binocular neurons and the shrinkage of cell bodies in the LGN (Berardi et al., in press). By contrast, intraventricular injections of NGF prevent the LGN cell body shrinkage induced by monocular deprivation (Domenici et al., 1991b).

(4) Responsiveness, spontaneous activity, and orientation selectivity of visual cortical cells were normal in NGF-treated animals, when measured both at the cnd and at different ages during the critical period. This suggests that NGF did not cause irritation in visual cortical neurons, nor did it interfere with the transmission of visual information, either excitatory or inhibitory. It should be noted that pharmacological treatments that interfere with normal neural activity, such as glutamate, bicuculline, and aminophosphonovalerate (APV), result in abnormal responsiveness and abnormal orientation selectivity of visual cortical neurons.

\section{$N G F$ in the visual system}

In the introductory remarks, we advanced the hypothesis that geniculate afferents compete at cortical level for a neurotrophic factor, the production of which is activity dependent. For NGF to be the neurotrophic factor in question, it is required that (1) NGF is present in the visual cortex during the critical period, (2) NGF production and/or uptake is dependent on electrical activity, and (3) NGF-specific receptors are present in the visual cortex and in particular on the afferent fibers from the LGN during the critical period.

As to the presence of NGF in the visual cortex, it is known that the content of NGF in the rat neocortex (Large et al., 1986) and visual cortex (Cremisi et al., 1991) and in the primate occipital cortex (Hayashi et al., 1990) is higher during the first part of the critical period, later decreasing to adult values. Whether the source of NGF is neuronal or glial is not yet clear. Astrocytes are known to produce NGF in vitro (Lu et al., 1991b). On the other hand, in the hippocampus, kainic acid lesions that spare glial cells abolish the content of mRNA for NGF (Ayer-LeLièvre et al., 1988; but see Bakhit et al., 1990).

There is already evidence that the production of neurotrophic factors of the NGF family can be dependent on electrical activity. It has been shown in the hippocampus that the regulation of mRNA levels for NGF and for another neurotrophic factor of the same family, brain-derived neurotrophic factor (BDNF), depends on neuronal activity, their upregulation being mediated via the glutamate receptors and their downregulation via the GABA system (Zafra et al., 1990; Ernfors et al., 1991; Lu et al., 1991b).

As far as the NGF receptor is concerned, controversy has recently arisen about the encoding gene and the associated protein that mediates the biological activity of NGF, that is, its high-affinity receptor (Hempsted et al., 1991; Klein et al., 1991; Weskamp and Reichardt, 1991).

Another consideration to be made is that neither the presence of NGF nor even the presence of the NGF-specific receptor in the visual cortex would be per sc cvidence that the only ncurotrophic factor possibly involved in cortical plasticity is NGF. Indeed, other neurotrophic factors bearing strong similarities with NGF, namely, BDNF (Barde et al., 1982) and neurotrophin-3 (NT3; Ernfors et al., 1990; Hohn et al., 1990; Jones and Reichardt, 1990; Kaisho et al., 1990; Maisonpierre et al., 1990a; Rosenthal et al., 1990), have been found in the rat cortex during development, although with different time windows and levels of expression. In particular, NT3 seems to be highly expressed only in earlier stages of development, in immature regions of the CNS where proliferation, migration, and differentiation of neuronal precursors are still ongoing (Maisonpierre et al., 1990b). At high concentrations (1000-fold excess of heterologous ligand), both BDNF and NT3 interact with NGF high-affinity receptors and vice versa (Rodriguez-Tebar et al., 1990). The amounts of NGF we have used (order of $1 \mu \mathrm{g}$ ) are very large if compared with the endogenous NGF level in the visual cortex, which is of the order of nanograms per gram of tissue (Large et al., 1986; Hayashi et al., 1990). We cannot rule out the possibility that what we observed is a cross-reaction, in that NGF has mimicked the action of other neurotrophic factors of the same family. It has to be noted that our hypothesis, namely, a role for neurotrophic factors target released in the formation of neural connections and, in particular, in visual cortical plasticity, does not depend on the exact nature of the trophic substance(s).

Our proposed hypothesis implies that the effects of monocular deprivation are due to lack of NGF that, in our experiment, is compensated by exogenous supply. There are, however, other possible explanations for the effects of NGF on monocular deprivation, which although possible on the basis of the current literature, turn out to be rather unlikely in view of our experimental findings.

(1) The effects of NGF could be indirect and mediated via cholinergic neurons. It is well known that NGF has a neurotrophic action on the cholinergic neurons of the CNS.

The visual cortex receives a substantial cholinergic input from the basal forebrain (Carey and Rieck, 1987), and according to Pioro and Cuello (1990), NGF receptor immunoreactivity (192 $\mathrm{IgG}$ ) in adult rat visual cortex is consistent with the pattern of cholinergic afferents. NGF could activate the cholinergic system and thus increase the cholinergic input onto visual neurons, which could in turn affect cortical plasticity. An increase in the cholinergic input onto visual neurons, however, is not necessarily expected to decrease cortical plasticity and thus prevent an ocular dominance shift. Indeed, the contrary has been reported in the literature; that is, a lesion to the cholinergic afferents decreases visual cortical plasticity (Bear and Singer, 1986). In addition, a variation in the cholinergic input to the visual cortex, in either direction, is expected to affect the spontaneous discharge and the cell responsiveness and stimulus selectivity (Sillito and Kemp, 1983; Sato et al., 1987), a finding confirmed also in the somatosensory cortex of awake undrugged rats (Delacour et al., 1990). We have failed to observe these effects. In addition, measurements of CHat activity (Domenici et al., 1991a) in the visual cortex of NGF-treated rats have shown that this parameter, which is an indicator of cholinergic activation, was not changed substantially by NGF treatment. 
(2) NGF could interfere with the normal development of the visual cortex that takes place within the first postnatal month, freezing the cortex in its immature state, with a high proportion of binocular cells. In this case, the functional properties of visual cortical cells in NGF-treated rats should be different from those found in normal rats of the same age. None of the functional properties tested (ocular dominance distribution, orientation selectivity) showed difference between normal and NGF-treated rats of any age. This suggests that the process of cortical development has not been affected by NGF treatment, in accordance with the observation that also visual acuity develops normally in NGF-treated rats (Domenici et al., 1991a,c) and kittcns (Maffei et al., in press). It may be noted that dark rearing, which is known to delay the development of the visual cortex, affects visual acuity and orientation selectivity of visual cortical cells (for cats, Timney et al., 1978; for rats, Maffei, Berardi, Domenici, Parisi, and Pizzorusso, unpublished observations).

A recent report by Ghosh and Shatz (1992) shows that subplate cells may be vital for normal ocular dominance development. Low-affinity NGF immunoreactivity has been transiently detected in the subplate region during the prenatal period in the cat (Allendorfer et al., 1990) and during prenatal and postnatal periods in the rat (Koh and Loy, 1989; Koh and Higgins, 1991). In the rat, the expression of low-affinity NGF receptors in the subplate region becomes undetectable by the end of the second postnatal week (Koh and Higgins, 1991). By this period, subplate cells seems also to disappear. In the experiments reported here, NGF treatment was started at P14, which is probably late to interfere with the function or survival of subplate cells, although we cannot exclude it.

In conclusion, the findings presented here together with similar results reported in kittens (Carmignoto et al., 1991) are consistent with the hypothesis that exogenous NGF compensates for a shortage of endogenous NGF due to sensory deprivation and that NGF action is exerted primarily on visual neurons. The recent finding obtained in this laboratory that the shrinkage induced by monocular deprivation in rat LGN cells is prevented by NGF treatment (Domenici et al., 1991b; Maffei et al., in press) is not contrary to this interpretation.

\section{References}

Albus K, Wolf W (1984) Early post-natal development of neuronal function in the kitten's visual cortex: a laminar analysis. J Physiol (Lond) 348:153-185.

Allendoerfer KL, Shelton DL, Shooter EM, Shatz CJ (1990) Nerve growth factor receptor immunoreactivity intransiently associated with subplate neurons in the mammalian cerebral cortex. Proc Natl Acad Sci USA 87:187-190.

Araujo DM, Chabot JG, Quirion R (1990) Potential neurotrophic factors in the mammalian central nervous system: functional significance in the developing and aging brain. Int Rev Neurobiol 32:141174.

Ayer-Lelièvre C, Olson L, Ebendal T, Seiger A, Persson H (1988) Expression of the $\beta$-nerve growth factor gene in hippocampal neurons. Science 240:1439-1441.

Baker FH, Grigg P, von Noorden GK (1974) Effects of visual deprivation and strabismus of the response of neurons in the visual cortex of the monkey, including studies on the striate and prestriate cortex in normal animals. Brain Res 66:185-208.

Bakhit C, Armanini M, Bennett GL, Wong W-LT, Hansen SE, Taylor R (1990) Glial cells increase the production of nerve growth factor (NGF) following destruction of hippocampal neurons. Soc Neurosci Abstr 16:207.2

Barde Y-A, Edgar D, Thoenen H (1982) Purification of a new neurotrophic factor from the mammalian brain. EMBO J 1:549-553.
Bear MF, Singer W (1986) Modulation of visual cortical plasticity by acetylcholine and noradrenaline. Nature 320:172-176.

Bear MF, Carnes KM, Ebner FF (1985) Postnatal changes in the distribution of acetylcholinesterase in the kitten striate cortex. J Comp Neurol 237:519-532.

Bear MF, Kleinschmidt A, Gu Q, Singer W (1990) Disruption of experience-dependent synaptic modifications in striate cortex by infusion of an NMDA receptor antagonist. J Neurosci 10:909-925.

Berardi N, Carmignoto G, Domenici L, Maffei L (1990) Intraventricular NGF injections prevent the effects of monocular deprivation in the rat. J Physiol (Lond) 422:9P.

Berardi N, Carmignoto G, Cremisi F, Domenici L, Maffei L, Parisi V, Pizzorusso T (1991) NGF prevents the change in ocular dominance distribution induced by monocular deprivation in the rat visual cortex. J Physiol (Lond) 434:14P.

Berardi N, Cattaneo A, Cellerino A, Domenici L, Fagiolini M, Maffei L, Pizzorusso $T$ (in press) Monoclonal antibodies to nerve growth factor (NGF) affect the postnatal development of the rat geniculocortical system. J Physiol (Lond), in press.

Blakemore C, Van Sluyters RC (1975) Innate and environmental factors in the development of the kitten's visual cortex. J Physiol (Lond) 248:663-716.

Boothe RG, Dobson MV, Teller DY (1985) Postnatal development of vision in human and nonhuman primates. Annu Rev Neurosci 8: 495-545.

Burne RA, Parnavelas JG, Lin CS (1984) Response properties of neurons in the visual cortex of the rat. Exp Brain Res 53:374- 383.

Carey RG, Rieck RW (1987) Topographic projections to the visual cortex from the basal forebrain of the rat. Brain Res 424:205-215.

Carmignoto G, Candeo C, Canella R, Comelli C, Maffei L (1989) Effect of NGF on the survival of retinal ganglion cells after section of the optic nerve. J Neurosci 9:1263-1273.

Carmignoto G, Canella R, Candeo P, Comelli MC (1991) Evidence for a role of NGF in neuronal plasticity of the cat visual system. Soc Neurosci Abstr 17:585.8.

Cremisi F, Domenici L, Pizzorusso T, Lombardo A, Bozzi Y, Maffei $\mathrm{L}$, Barsacchi $\mathrm{G}$ (in press) Role of NGF in the developing visual system of the rat. Eur J Cell Biol Abstr, in press.

Dean P (1990) Sensory cortex: visual perceptual functions. In: The cerebral cortex of the rat (Kolb B, Tees RC, eds), pp 275-307. Cambridge, MA: MIT Press.

Delacour J, Houcine O, Costa JC (1990) Evidence for a cholinergic mechanism of "learned" changes in the responses of barrel field neurons of the awake and undrugged rat. Neuroscience 34:1-8.

Domenici L, Berardi N, Carmignoto G, Vantini G, Maffei I, (1991a) Nerve growth factor prevents the amblyopic effects of monocular deprivation. Proc Natl Acad Sci USA 88:8811-8815.

Domenici L, Cellerino A, Maffei L (1991b) NGF prevents the shrink age of neurons in the lateral geniculate nucleus (LGN) of monocularly deprived rats. Soc Neurosci Abstr 17:451.22.

Domenici L, Berardi N, Carmignoto G, Pizzorusso T, Parisi V, Maffei L (1991c) Nerve growth factor (NGF) prevents the effects of monocular deprivation in the rat. In: Maturation and aging in the CNS, Vol 222, The changing visual system (Bagnoli P, Hodos W, eds), pp 333-345. New York: Plenum.

Dräger UC (1978) Observations on monocular deprivation in mice. J Neurophysiol 41:28-42.

Edwards AL (1961) Statistical methods for the behavioral sciences. New York: Holt, Rinehart and Winston

Ernfors P, Tbanez CF, Ebendal T, Olson L, Persson H (1990) Molecular cloning and neurotrophic activities of a protein with structural similaritics to ncrve growth factor: developmental and topographical expression in the brain. Proc Natl Acad Sci USA 87:5454-5458.

Fifkova E (1968) The effect of unilateral deprivation on visual centers in rats. J Comp Neurol 140:431-438.

Ghosh A, Shatz CJ (1992) Involvement of subplate neurons in the formation of ocular dominance columns. Science 255:1441-1443.

Giffin F, Mitchell DE (1978) The rate of recovery of vision after early monocular deprivation in kittens. J Physiol (Lond) 274:511-537.

Guillery RW, Stelzner DJ (1970) The differential effects of unilateral lid closure upon the monocular and binocular segments of the dorsal geniculate nucleus in the cat. J Comp Neurol 139:413-422.

Harwerth RS, Smith EL III, Crawford MLJ, von Noorden GK (1989) The effects of reverse monocular deprivation in monkeys. I: Psychophysical experiments. Exp Brain Res 74:327-337. 
Hayashi M, Yamashita A, Shimizu K (1990) Nerve growth factor in the primate central nervous system: regional distribution and ontogeny. Neuroscience 36:683-689.

Hebb DO (1949) Organization of behavior. New York: Wiley.

Hempsted BL, Martin-Zanca D, Kaplan DR, Parada LF, Chao MV (1991) High-affinity NGF binding requires coexpression of the trk proto-oncogene and the low-affinity NGF receptor. Nature 350:678683.

Hendry IA (1989) In vivo administration of nerve growth factor. In: IBRO handbook series, Vol 12, Nerve growth factors (Rush RA, ed). New York: Wiley.

Hohn A, Leibrock J, Bailey K, Barde Y-A (1990) Identification and characterization of a novel member of the nerve growth factor/brain derived neurotrophic factor family. Nature 344:339-341.

Hubel DH, Wiesel TN (1962) Receptive fields, binocular interaction and functional architecture in the cat's visual cortex. J Physiol (Lond) 160:106-154.

Hubel DH, Wiesel TN (1963) Receptive fields of cells in striate cortex of very young, visually inexperienced kittens. J Neurophysiol 26:994 1002.

Hughes A (1979) A schematic eye for the rat. Vision Res 19:569-588.

Jones KR, Reichardt LF (1990) Molecular cloning of a human gene that is a member of the nerve growth factor family. Proc Natl Acad Sci USA 87:8060-8064.

Kaisho Y, Yoshimura K, Nakahama K (1990) Cloning and expression of a cDNA encoding a novel human neurotrophic factor. FEBS Lett 266:187-191.

Kasamatsu T, Pettigrew JD (1976) Depletion of brain catecholamines: failure of ocular dominance shift after monocular occlusion in kittens. Science 194:206-209.

Klein R, Jing S, Nanduri V, O'Rourke E, Barbacid M (1991) The trk proto-oncogene encodes a receptor for nerve growth factor. Cell 65: 189-197.

Koh S, I oy R (1989) I ocalization and development of NGF-sensitive rat basal forebrain neurons and their afferent projections to hippocampus and cortex. J Neurosci 9:2990-3018.

Koh S, Higgins GA (1991) Differential regulation of the low- affinity nerve growth factor receptor during postnatal development of the rat brain. J Comp Neurol 313:494-508.

Kromer LF (1987) Nerve growth factor treatment after brain injury prevents neuronal death. Science 235:214-216.

Large TH, Bodary SC, Clegg DO, Weskamp G, Otten U, Reichardt LF (1986) Nerve growth factor gene expression in the developing rat brain. Science 234:352-355.

I ennie P, Perry VH (1981) Spatial contrast sensitivity of cells in the lateral geniculate nucleus of the rat. J Physiol (Lond) 315:69-79.

LeVay S, Wiesel TN, Hubel DH (1980) The development of ocular dominance columns in normal and visually deprived monkeys. $\mathrm{J}$ Comp Neurol 191:1-51.

Levi-Montalcini $\mathbf{R}$ (1987) The nerve-growth factor 35 years later. Science 237:1154-1162.

Lindgren BW (1960) Statistical theory. London: Macmillan.

Lu B, Yokohama M, Dreyfus CF, Black IB (1991a) Depolarizing stimuli regulate nerve growth factor gene expression in cultured hippocampal neurons. Proc Natl Acad Sci USA 88:6289-6292.

Lu B, Yokohama M, Dreyfus CF, Black IB (1991b) NGF gene expression in actively growing brain glia. J Neurosci 11:318-326.

Maffei L, Berardi N, Carmignoto G, Cellerino A, Domenici L, Fiorentini A, Pizzorusso $T$ (in press) Role of neurotrophic factors in the plasticity of the mammalian visual system. In: Proceedings of the retina research symposia (Lam M-K, Broy G, eds). Cambridge, MA: MIT Press.

Maisonpierre PC, Belluscio L, Squinto S, Ip NY, Furth ME, Lindsay RM, Yancopoulos GD (1990a) Neurotrophin-3: a neurotrophic factor related to NGF and BDNF. Science 247:1446-1451.

Maisonpierre PC, Belluscio L, Friedman B, Alderson RF, Wiegand SJ, Furth ME, Lindsay RM, Yancopoulos GD (1990b) NT-3, BDNF and NGF in the developing rat nervous system: parallel as well as reciprocal patterns of expression. Neuron 5:501-509.

Montero VM, Bruggge JF, Beitel RE (1968) Relation of the visual field to the lateral geniculate body of the albino rat. J Neurophysiol 31:221-236.

Parnavelas JG, Burne RA, Lin CS (1981) Receptive field properties of neurons in the visual cortex of the rat. Neurosci Lett 27:291-296.
Paxinos G, Watson C (1986) The rat brain in stereotaxic coordinates 2d ed. Sydney: Academic.

Pioro EP, Cuello AC (1990) Distribution of nerve growth factor receptor-like immunoreactivity in the adult rat central nervous system. Effect of colchicine and correlation with the cholinergic system. I. Forebrain. Neuroscience 34:57-87.

Polyak S (1957) The vertebrate visual system. Chicago: University of Chicago.

Ramoa AS, Paradiso MA, Freeman RD (1989) Blockade of intracortical inhibition in kitten striate cortex: effect on receptive field properties and associated loss of ocular dominance plasticity. Exp Brain Res 73:285-296.

Reese BE (1988) "Hidden lamination" in the dorsal lateral geniculate nucleus: the functional organization of this thalamic region in the rat. Brain Res Rev 13:119-137.

Reese BE, Jeffery G (1983) Crossed and uncrossed visual topography in dorsal lateral geniculate nucleus of the pigmented rat. J Neurophysiol 49:877-885.

Reiter HO, Stryker MP (1987) Neural plasticity without postsynaptic action potentials: less-active inputs become dominant when kitten visual cortical cells are pharmacologically inhibited. Proc Natl Acad Sci USA 85:3623-3627.

Rodriguez-Tebar A, Dechant G, Barde YA (1990) Binding of brainderived neurotrophic factor to the nerve growth factor receptor. Neuron $4: 487-492$.

Rosenthal A, Goeddel DV, Nguyen T, Lewis M, Shih A, Laramee GR, Nikolics K, Winslow (1990) Primary structure and biological activity of a novel human neurotrophic factor. Neuron 4:767-773.

Rothblat LA, Schwartz ML (1979) The effect of monocular deprivation on dendritic spines in visual cortex of young and adult albino rats: evidence for a sensitive period. Brain Res 161:156-161.

Rothblat LA, Schwartz ML, Kasdan PM (1978) Monocular deprivation in the rat: evidence for an age-related defect in visual behavior. Brain Res 158:456-460.

Sanes DH, Constantine-Paton M (1983) Altered activity patterns during development reduce natural tuning. Science 221:1183-1185.

Sato H, Hata Y, Masui H, Tsumoto T (1987) A functional role of cholinergic innervation to neurons in the cat visual cortex. J Neurophysiol 58:765-780.

Sefton AJ, Dreher B (1985) Visual system. In: The rat nervous system (Paxinos G, ed), pp 169-221. Sydney: Academic.

Shatz CJ (1990) Impulse activity and the patterning of connections during CNS development. Neuron 5:745-756.

Shatz CJ, Stryker MP (1978) Ocular dominance in layer IV of the cats visual cortex and the effects of visual deprivation. I Physiol (Lond) 281:267-283.

Shaw C, Cynader M (1984) Disruption of cortical activity prevents ocular dominance changes in monocularly deprived kittens. Nature 308:731-734.

Sherman SM, Guillery RW, Kaas JH, Sanderson KJ (1974) Behavioral, electrophysiological and morphological studies of binocular competition in the development of the geniculo-cortical pathways of cats. J Comp Neurol 158:1-18.

Sillito AM, Kemp JA (1983) Cholinergic modulation of the functional organization of the cat visual cortex. Brain Res 289:143-155.

Simons DJ, Land PW (1987) Early experience of tactile stimulation influences organization of somatic sensory cortex. Nature 326:694697.

Stafford CA (1984) Critical period plasticity for visual function: definition in monocularly deprived rats using visually evoked potentials. Ophthalmic Physiol Opt 4:95-100.

Stryker MP, Strickland SL (1984) Physiological segregation of ocular dominance columns depends on the pattern of afferent electrical activity. Invest Ophthalmol Vis Sci 25[Suppl 3]:278.

Thoenen H (1991) The changing scene of neurotrophic factors. Trends Neurosci 14:165-170.

Thurlow GA, Cooper RM (1988) Metabolic activity in striate and extrastriate cortex of the hooded rat: contralateral and ipsilateral eye input. J Comp Neurol 274:595-607.

Timney B, Mitchell DE, Giffin F (1978) The development of vision in cats after extended periods of dark rearing. Exp Brain Res 31:547560.

Vantini G, Schiavo N, Di Martino A, Polato P, Triban C, Callegaro L, Toffano G, Leon A (1989) Evidence for a physiological role of nerve 
growth factor in the central nervous system of neonatal rats. Neuron 3:267-273.

Weskamp G, Reichardt LF (1991) Evidence that biological activity of NGF is mediated through a novel subclass of high affinity receptors. Neuron 6:649-663.

Wiesel TN, Hubel DA (1963) Single cell responses in striate cortex of kittens deprived of vision in one eye. J Neurophysiol 26:1003-1017.
Zafra F, Hangerer B, Leibrock J, Thoenen H, Lindholm D (1990) Activity dependent regulation of BDNF and NGF mRNAs in the rat hippocampus is mediated by non-NMDA glutamate receptors. EMBO J 9:3545-3550.

Zilles K, Wree A, Schleicher A, Divac I (1984) The monocular and binocular subfields of the rat's primary visual cortex: a quantitative morphological approach. J Comp Neurol 226:391-402. 